\title{
Issues, Challenges, and Suggestions for Empowering Technical Vocational Education and Training Education during the COVID-19 Pandemic in Malaysia
}

\author{
Chye Fhern Yeap, Najibah Suhaimi, M. Khalid M. Nasir* \\ Universiti Kebangsaan Malaysia (UKM), Bangi, Malaysia \\ Email: snajibah12@gmail.com, carynyeap@gmail.com, *mdkhalid@ukm.edu.my
}

How to cite this paper: Yeap, C. F., Suhaimi, N., \& Nasir, M. K. M. (2021). Issues, Challenges, and Suggestions for Empowering Technical Vocational Education and Training Education during the COVID-19 Pandemic in Malaysia. Creative Education, 12, 1818-1839.

https://doi.org/10.4236/ce.2021.128138

Received: July 6, 2021

Accepted: August 3, 2021

Published: August 6, 2021

Copyright $\odot 2021$ by author(s) and Scientific Research Publishing Inc. This work is licensed under the Creative Commons Attribution International License (CC BY 4.0).

http://creativecommons.org/licenses/by/4.0/ Open Access

\begin{abstract}
Technical Vocational Education and Training (TVET) is one of the critical drivers in the transformation of Malaysia's education system and contributes towards economic growth. It works to develop and equip individuals with current technical skills based on industry demand. Many issues faced by the government in the way to strengthen the field of Technical and Vocational Education and became worse when the outbreak of COVID-19 pandemic changed the way of delivering education from conventional methods to e-learning. Hence, the main thrust of this review paper is to highlight the issues of TVET education and challenges TVET education faced during the COVID-19 pandemic. For the findings, articles related with issues and challenges in TVET education during pandemic outbreak are chosen from SCOPUS, WOS and ERIC databases. The results have reported that lack of student motivation and career counselling, stigma towards TVET education, lecturer's competency and inadequacies of infrastructure resources in TVET are issues that happen in TVET education throughout the years while internet connectivity problem, learning platform, content of curriculum and assessment, the readiness of trainers and trainees for e-learning have been discussed as challenges of TVET education during COVID-19 pandemic.
\end{abstract}

\section{Keywords}

COVID-19 Pandemic, TVET Education, Issues, Challenges, E-Learning

\section{Introduction}

The main objective of Malaysian education system is to ensure the children 
choose the right education pathway and help them to develop 21st century skills. Therefore, alternative, attractive and viable pathways were offered for individual students such as academic, technical, vocational, religions, sports, or arts (Ministry of Education Malaysia, 2013). Under the Malaysian Education Blueprint 2015-2025, one of the key aspirations for Technical Training and Vocational Education (TVET) is for it to be on an equal footing with traditional academic pathways. This pathway was created to provide more opportunities for students to learn from basic to advanced levels in science and technology education across a wide range of institutions. This effort is to train students to become skilled and semi-skilled workers to meet the labour supply for the local industry (Sauffie, 2015).

TVET programs in Malaysia offered at certificate, diploma and degree levels by various institutions under seven ministries, state and private skills development centres (Aziz et al., 2020). TVET is the key driver in achieving a fully developed and high-income nation by producing k-workers to the labour market. Therefore, Malaysia government has consistently provided support for TVET especially in setting up specialized skills training entities such as the Industrial Training Institute, National Youth Skills Institute, National Skills Institute, Vocational College and private skills training institutions. At present, Malaysia has 87 vocational colleges, 357 schools offering Pendidikan Vokasional Menengah Atas, 26 schools offering Perantisan Industri Menengah Atas, nine Sekolah Menengah Teknik and four Sekolah Menengah Pendidikan Khas Vokasional (Krishnan, 2020).

Starting at the end of 2019, COVID-19 pandemic has affected the health of hundreds of thousands of people, claimed many lives, disrupted learning and training, and threatened economies worldwide including Malaysia. Therefore, the Malaysia government decided to impose the Movement Control Order (MCO), which had brought a big impact and challenges to the education system in Malaysia that forced the shift to online learning. The Sri Lanka government also introduced technologies used for online and distance learning as a new norm for TVET instructors and students during the COVID-19 pandemic (Hayashi et al., 2021). Thus, online teaching and learning is the only way to mitigate learning disruption during the MCO period in Malaysia (Sufian et al., 2020; Hasin \& Nasir, 2021).

While online teaching and learning is not new in Malaysia. The advent of ICT and the Internet has greatly influenced the way knowledge is transmitted. According to Ngampornchai and Adam (2016), e-learning is the learning supported with electronic technology such as online classes and portals to access the courses outside the classroom. However, the of implementation of ICT among TVET students is more effective in developing cognitive learning compared to occupational hands-on skills (Yasak \& Alias, 2015). Ahmad et al. (2019) also supported many available standards or models in the Learning Management System (LMS) focusing on cognitive domain and no guidelines in designing effective LSM for TVET in Malaysia. Although, the attitude of instructors and 
students toward implementing ICT was positive. In fact, some instructors are low skill in integrated ICT in the classroom due to conventional teaching habits preferred than implementing ICT in teaching method (Munyi et al., 2021).

Besides that, learning facilities could be a barrier in implementing online learning across the TVET courses. The study from Zulkifli et al. (2020) states that the main obstacle in using Massive Open Online Courses (MOOCs) among students at polytechnic in Malaysia is the internet coverage even though students are committed towards using MOOCs. According to Yasak and Alias (2015), the main challenges in implementing online learning for TVET are development of technology, infrastructure and human resource, and management, economic and policy issues. However, the effectiveness of pedagogy approaches and assessment methods in online learning are seldom discussed (Nasir, 2020). With the current educational practices and technological development, other online learning integration such as application of software and hardware in online learning, social media networks, and webinars also need to be considered (Nasir et al., 2018).

As the technology is used widely during pandemic, all parties are facing many issues and challenges during online learning as the conventional teaching and learning including technical and hands-on skills are more needed for TVET students rather than online learning. In this article, some issues and challenges will be discussed such as lack of student motivation and career counselling, stigma towards TVET graduates, lecturer's competency and inadequacies of infrastructure resources, and readiness of institutes, instructors and students in a new norm of learning. Meanwhile, suggestions also stated for policy makers, TVET institutions, instructors and parents.

\section{Issues of TVET Education in Community College and Vocational School}

There are several issues faced by TVET education stated at Malaysia Education Blueprint 2013-2025 that is to meet the 60 Science: 40 Arts policy to deliver the workforce needs of Malaysia's economic demand (Ministry of Education Malaysia, 2013). According to Omar et al. (2020), factors responsible for TVET students' low enrolment include lack of student motivation and career counselling, stigma towards TVET graduates, government passive attitude towards TVET and inadequacies of infrastructure resources.

\subsection{Lack of Student Motivation and Career Counselling}

Several factors might affect students' motivation to enrol in TVET programs. According to Omar et al. (2020), three factors like intrinsic, extrinsic and altruistic motivations influence students to choose a TVET program as their career among Malaysian. Many perceptions have grown towards technical education as TVET education especially for low-income students, school dropouts and low grades students. Omar et al. (2020) also supported that TVET program is for lower grades students and weak socio-economics backgrounds which is consi- 
dered as a second choice after university. Even though the government constructs many initiatives for TVET students, the parents and students are more focusing on university education rather than TVET education. Moreover, an interview with parents and students also highlighted the low interest and enrolment in TVET due to the lack of awareness of the vocational pathway and career opportunities (Ministry of Education Malaysia, 2013). Furthermore, most parents' influence will affect their choices in higher education. According to Dyrin et al. (2021), parents' educational background determines their children's education. They reported that low parents' educational backgrounds prefer university education for their children rather than TVET education for their benefit and status.

Hence, career counselling is important for students and parents to explore and guide students in choosing their professional career based on their strengths, weaknesses, resources and opportunities. Therefore, career counselling and vocational guidance services play an important role in empowering students to select the best-fit education pathway (Arshad et al., 2018). However, deficient career counselling among TVET students influence their career exploration behaviours. Tadele and Terefe (2018) studied the relationship between career self-efficacy beliefs and career exploration behaviours among TVET students, which stated that the students who have high career self-efficacy will be affected positively in career exploration behaviours.

\subsection{Stigma towards TVET Education}

Besides, the stigma towards TVET education is divided into the meaning of TVET programs itself and the attitude of parents towards TVET education. According to Mahuyu and Makochekanwa (2020), most parental perceptions of TVET education are that TVET students are categorized by low performers and socio-economic, weak in academic achievement, dirty work and unorganized. Traditionally, vocational education has been identified with educational provision that focused on training rather than engaging in "education" because directed to occupational learning for types of work that are seen as requiring only lower-level skills (Moodie, 2002). Other than that, some parents emphasize academic achievement at schools rather than the skills and interest of students, which lead to low enrolment in TVET programs and vocational schools.

Community perceptions also contribute to negative perceptions among parents in TVET training programs such as they are prouder of the excellent youth from universities than TVET trainers. They felt that TVET trainers do not have a bright future in jobs. Hong et al. (2021) stated some negative feedback influenced parents and negative perception from close relatives cause low student admission in TVET institutions. Besides, Ismail and Abiddin (2014) also stated that many employers poorly perceived and recognized the TVET-based qualifications and careers in the workplace. The highly fragmented landscape, with many ministries and agencies issuing certifications cause the employers do not recognize the certification. 


\subsection{Lecturer's Competency and Inadequacies of Infrastructure Resources}

It is essential to have competent and skilled vocational lecturers or teachers for an effective teaching and learning process in TVET because TVET focuses on training students equipped with technical knowledge and skills to fulfil the job market (Ismail et al., 2018). Unfortunately, due to the shortage of qualified teaching staff in TVET, many teaching staff are hired directly after study in university or college based on their academic qualifications without considering their skills (Ismail \& Abiddin, 2014). The study of Hanapi et al. (2015) stated that the incompetent teachers in teaching methods and classroom management, lack of industrial experiences, and not interesting in teaching the assigned subjects were contributed to the unemployment of vocational and technical students in Malaysia. Despite this, the study of Ismail et al. (2018) stated that vocational teachers found difficulty in attending professional development programs to enhance their knowledge, skills, and professionalism due to limited budget allocation, rotation system, and heavy workload.

A well-established and functional workshop with the right tools, equipment, machines and facilities is important to ensure the effective implementation of the TVET program (Bakri \& Zakaria, 2018). TVET program is built to enhance practical skills in construction, improve well-operate design and repair skills for infrastructural and machinery facilities, and strengthen employable skills among students (Omar et al., 2020). In reverse, a lack of educational facilities and equipment (Hong et al., 2021), teaching and learning services and insufficiency of curriculum adjustment for business needs and less industrial linkage cause less enrolment in community college (Sitepu et al., 2020) and TVET institutions. Besides, political insecurities, outdated projects and improper checking of curriculum have been issued and caused incompetence of students' skills, knowledge and motivation (Nasir et al., 2021).

\section{Challenges TVET Education during Pandemic}

The COVID-19 pandemic did not only cause conventional teaching and learning (T\&L) to be delayed but also challenged the educator to adapt to the new norms that required the T\&L process to be implemented online in order to deliver their assignments.

\subsection{Institutes' Readiness to the New Norm Learning}

Public and private TVET providers are suggested to conduct their training and theory courses online during the MCO period. The ability of TVET institutions to implement e-learning depends on the capacity to adapt curriculum as well as the preparedness of infrastructures such as internet connectivity, devices or media, learning platforms and the readiness of trainers and teachers for online learning (UNESCO-UNEVOC International Centre, 2020). TVET institutions should revise the management, T\&L models, and assessment for e-learning be- 
fore implementation. Some programs or academic subjects that do not require manual activities can switch to e-learning more easily. For example, the cyber security course will be relatively easy to conduct online learning compared to automobile mechanics courses that require hands-on practice. According to Menon (2020), courses like administrative management, management systems, programming and IT courses can be conducted online easily.

For the TVET curriculum, it is a big challenge to migrate to distance and online learning because TVET focuses more on practical skills and work-readiness. Practical skills acquired through learning-by-doing, which occurs in school-based workshops and laboratories or through hands-on experience at the workshop. Some practical exercises require the use of specific equipment or materials that make e-learning approaches a weak substitute to conventional methods (Hoftijzer et al., 2020). The highly practical nature of TVET makes e-learning only useful for the theoretical type of subjects but the practical part in TVET needs further solutions. This situation becomes worse when many trainees or students are forced out of job for temporary or full-term when many businesses close due to being unable to buffer the cost (Majumdar \& Araiztegui, 2020).

\subsection{Instructors' Readiness to the New Norm Learning}

Before the outbreak of the COVID-19, e-learning was not the preferred method used by the instructors in TVET institutions due to the programs focusing more on practical components. According to the study from UNESCO-UNEVOC International Centre (2020), nearly a third of all respondents out of 126 countries, did not use e-learning at all, another third used e-learning occasionally, 17 percent used e-learning regularly, and merely 11 percent used it very often. However, affected by the COVID-19 pandemic, TVET institutions need to shift from conventional teaching methods to online learning in response to the lockdown. This ad hoc response dramatically changes the teaching method used by instructors and they need to adapt to new teaching mediums. Some instructors may lack skills in e-learning usage and integrating ICTs in T\&L. This is supported by Dumbiri and Nwadiani (2020) stating that some instructors are not familiar with e-learning facilities utilization skills and they require training in basic skills for e-learning.

Instructors may also need to adapt in pedagogies approaches, strategies and methods, classroom management, and assessment in response to the new norm in T\&L processes. The readiness of instructors for e-learning needs to be considered because they need time to prepare for teaching materials and to improve their IT skills as well as online pedagogy and evaluation skills. These are important elements for instructors to engage and conduct their lesson effectively through e-learning (Nasir et al., 2018; Nasir, 2020). The study from Lie et al. (2020) stated that teachers' prior exposure to online learning, technological knowledge, pedagogical knowledge, and the support system are factors related to the level of engagement of instructors in online learning. Besides, instructors also face heavy workload 
with new normal teaching methods and increased messages and questions from students at all hours (UNESCO-UNEVOC International Centre, 2020).

Moreover, some lecturers prefer conventional teaching methods over online teaching because the engagement between the students and lecturers are reduced due to the lack of ICT skills among lecturers and low collaboration between students during online learning (Thangaiah et al., 2020; Nasir et al., 2018). The study from Thangaiah et al. (2020) about the usage of e-learning among TVET students and instructors also stated that many students are not participate actively in online learning due to lack of time, insufficient infrastructure facilities, less exposure to VLE Frog, inability to access the internet and frequent changes in curriculum of vocational courses. Due to this factor, instructors refused ICT implementations and it is difficult to handle online classes during pandemic COVID-19.

\subsection{Students' Readiness to the New Norm Learning}

The world's school students which roughly around 1.6 billion or $91.3 \%$ have been affected by system closures during the COVID-19 (UNESCO, 2020). In order to mitigate the losses in learning, e-learning has been implemented in schools and higher learning institutions to ensure a smooth process of T\&L. There are several challenges related to e-learning faced by students including lack of necessary remote training skills, require more time in preparing videos or online learning, insufficient internet connectivity, expensive data package, usability of learning platforms, student friendly content (UNESCO-UNEVOC International Centre, 2020), restricted open online resources and online teaching solution availability (Majumdar \& Araiztegui, 2020). The study from Hassan et al. (2020) also stated that the connection of internet networks affected the motivation of students in using e-learning. This situation will lead to higher dropout rates as some students become unmotivated. The motivation of some students also greatly affected due to the passive methods of engaging with e-learning content such as reading, video conferencing, watching demonstrations, videos, and the delay in the acquisition of hands-on practical experience due to the closure of businesses (UNESCO-UNEVOC International Centre, 2020).

Although Malaysia was the third best across South East Asia in Internet penetration (Jalli, 2020), the access to Internet in different states in Malaysia is not the same. Some remote areas do not have adequate Internet access (Ating, 2020) even though the statistics show increased penetration every year (Jalli, 2020). The infrastructural gap such as the discrepancy of Internet speeds in different regions will affect students' access to e-learning (Jalli, 2020). This is supported by Chong (2020) stating that location and Internet budget have different coverage and speed of the internet. Some students from rural areas may not enjoy Internet access or sufficiently good Internet access compared to their peers in urban areas. Hence, online learning will run a high chance of being left behind for those rural students.

According to The World Bank (2020), TVET students come from disadvantaged households compared to students in similar levels of general education in 
many countries. In Malaysia, most students who join skills training institutes come from poor homes and populate in remote areas with very poor internet connection (Menon, 2020). Many students did not participate in the e-learning sessions due to lack of gadgets, unable to buy data and an unconducive learning environment as they are from the B40 (low-income) community. These students from low economic backgrounds will suffer more as they study at home and they no longer enjoy the facilities such as computers to work, photocopy machines, internet access and a quiet space to study (Chong, 2020). Therefore, students may draw more expenses due to the need to subscribe to better Internet packages and buy laptops. Furthermore, insufficient internet access and less equipment among unfortunate students are the obstacles to e-learning.

Moreover, the closure of businesses prevents students from carrying out practical training, which is an important aspect for TVET due to its focus on practical skills and work-readiness. These students are facing serious disruption from the lockdowns because laboratory-based training and work-based learning either stopped or continue to be conducted in restricted numbers with strict sanitary measures (ILO, 2020). In Australia, work placement has been rescheduled and practical components of TVET using industry equipment are not permitted currently (ILO, 2020). Students who are involved in apprentices and interns are also affected by the disruption with the loss of several weeks or months of learning and training likely to affect the outcomes. The postponement of apprenticeships and internships may cause the delay in completion of study. Thus, they may face problems in sponsorship as the graduation will be delayed and their academic performance will be affected (Nassr et al., 2020).

Besides, certifying exams and assessments have also been postponed for TVET trainees and students in many countries including Malaysia (ILO, 2020). Although immediate response has been taken to shift face-to-face classroom teaching to e-learning, some practical courses could not be delivered online, and the assessment and certification process cannot be conducted well. According to the International Labour Organization (2020), programs with significant practical modules are prolonged and rescheduled to another date, as they require some face-to-face assessments. Thus, the extension of the school year happened due to the inability to conduct assessments in programs. These circumstances may burden the TVET students financially because they might not be able to pay the tuition fees and extension of completion study might affect them to have certification to apply for a job.

\section{Summary of Issues and Challenges in Malaysia TVET}

Table 1 shows the summary on the issues and challenges of TVET that have been discussed previously. There are three issues in Malaysia TVET which are lack of student motivation and career counselling, stigma towards TVET education and lecturer's competency and inadequacies of infrastructure resources. Meanwhile, there are challenges that arise due to COVID-19 pandemic such as institutes', instructors' and students' readiness to the new norm of learning. 
Table 1. Summary of issues and challenges of TVET before and after COVID-19.

\section{Issues in Malaysia TVET throughout the year}

\begin{tabular}{|c|c|}
\hline $\begin{array}{l}\text { Lack of student } \\
\text { motivation and } \\
\text { career counselling }\end{array}$ & $\begin{array}{l}\text { There are three factors which are intrinsic, extrinsic and altruistic } \\
\text { motivations will influence students to choose a TVET curriculum as their } \\
\text { higher education after secondary school (Omar et al., 2020). According } \\
\text { to Omar et al. (2020), TVET programs are basically provided for lower } \\
\text { grades and weak socio-economics backgrounds students. Hence, many } \\
\text { negative perceptions have grown and influenced student's motivation in } \\
\text { choosing TVET education. Besides, deficient career counselling from } \\
\text { TVET counsellor affect their interest in TVET program. }\end{array}$ \\
\hline $\begin{array}{l}\text { Stigma towards TVET } \\
\text { education }\end{array}$ & $\begin{array}{l}\text { Parents and community are the most influential factors that affect } \\
\text { students' motivation in pursuing TVET programs. Mahuyu and } \\
\text { Makochekanwa (2020) stated that perceptions of TVET curriculum are } \\
\text { low performers and socio-economic, weak in academic achievement, } \\
\text { dirty work and unorganized. Furthermore, TVET-based qualifications } \\
\text { and careers are not well known-well in the workplace and difficult to } \\
\text { have a bright future in jobs (Ismail \& Abiddin, 2014). }\end{array}$ \\
\hline $\begin{array}{l}\text { Lecturer's competency } \\
\text { and inadequacies of } \\
\text { infrastructure resources }\end{array}$ & $\begin{array}{l}\text { Shortage of qualified teaching staff and skills in technical and vocational } \\
\text { caused incompetence in teaching methods and classroom management, } \\
\text { not interested in assigned subjects among lecturers (Hanapi et al., 2015). } \\
\text { Besides, vocational lecturers find it difficult to enhance their knowledge } \\
\text { and skills due to lack of budget, rotation system and heavy workload } \\
\text { (Ismail et al., 2018). Hong et al. (2021) also supported the statement } \\
\text { where insufficiency of curriculum adjustment and less industrial linkage } \\
\text { cause low enrolment in community college. }\end{array}$ \\
\hline
\end{tabular}

Challenges in Malaysia TVET during outbreak COVID-19 pandemic

It is difficult to migrate into online learning as TVET curriculum focuses

Institutes' readiness to the new norm learning

Instructors' readiness to the new norm learning

Students' readiness to the new norm learning more on practical skills and work readiness. Some practical skills cannot be done at home as some specific tools and equipment only provided by the institutions (Hoftijzer et al., 2020). This situation becomes worse when many businesses close and effect students' internship period as they are unable to buffer the cost (Majumdar \& Araiztegui, 2020).

Due to the pandemic COVID-19 outbreak, all education institutions must be closed to prevent widespread among students. This ad hoc response dramatically changes the teaching method and adapt with new norm teaching quickly. However, most instructors lack skills in e-learning usage and integrating ICTs in teaching pedagogy (Dumbiri \& Nwadiani, 2020). Besides, longer time is needed to prepare teaching materials and improve IT skills before class (Lie et al., 2020). Furthermore, low collaboration with students also disrupted the online teaching and caused less ICT implementation in online teaching.

Most students face problem with limited internet connectivity, remote training skills and lack of digital tools due to low socio-economics background. Besides, low motivation due to burnout from online learning also affected the collaboration in assessment and assignment among students (UNESCO-UNEVOC International Centre, 2020).

\section{Suggestions}

As steps to lessen the long-term impact of the COVID-19 pandemic, Malaysia government needs to establish strategies and approaches corresponding to the preparedness of countries to tackle the issue in different fields, especially in 
education. Few suggestions have stated for the provider and policy maker, TVET institutions, instructors, and parents to empower the TVET program during COVID-19 pandemic.

\subsection{The Provider and Policy Maker}

An immediate response of the government to address the challenges when switching from face-to-face classroom learning to e-learning is solving the penetration of the internet among the students and educators. Although Malaysia government has taken initiative to provide 1 GB free internet per day for online teaching and learning through selected telco companies throughout the MCO (Ating, 2020), the data provided might not be enough to fully apply e-learning. Governments should increase Internet penetration in rural areas by providing affordable remote satellites for Internet connection (Jalli, 2020). While this is the right direction to go, this has complemented with affordable and reliable Internet packages and wider coverage in various parts of Malaysia (Chong, 2020).

At the same time, the government should take initiative by providing instruments needed for e-learning such as computers, printers, broadband networks or smartphones. Governments could introduce an "affordable device program" by giving special incentives to the qualified community, to ensure that all families own at least one compatible device for e-learning (Jalli, 2020). To cater to certain households' incapability to purchase these gadgets, the government also introduced Kelas@Rumah program, which is a daily television show that is available on a free-to-view television channel (Ating, 2020). Unfortunately, this program mainly focused on primary and secondary school's syllabus but not for TVET students. However, in China, a team of TVET teachers has been established to develop online courses that are delivered through multiple platforms including a new TV channel for TVET to improve the quality of emergency remote teaching (COL, 2020).

The policy maker needs to come out with a guideline to mitigate the interruption the learning process has on students. Guidelines are important as they provide direction on implementing programs that are mainly practical in nature, via e-learning and also ensure that there will be no serious disruption to learning. Without guidelines, it will be difficult for the provider to adhere to the systems and standards of the National Occupational Skills Standards (NOSS) (Menon, 2020). Therefore, it was a good opportunity for the policy maker and other bodies to create a common e-learning platform for all skills training institutes and standardized all theory and practical components, guidelines and measures that meet the Performance Criteria and Assessment Criteria including safety, attitude and application of equipment aspects as set out in the NOSS (Menon, 2020). Besides, the guidelines provided are important to ensure home-based skills teaching and training are carried out as planned in a safe environment and be effectively implemented by the institutes' management.

As classes change to online in the near future, the government will need to strengthen cyber security to prevent computers, electronic systems and networks 
from malicious attacks (Chong, 2020). Government needs to enforce policies on the security and ethics of technology to protect the personal data of both students and staff in the country. This is because LMS applications and social media platforms have a higher risk of exposing student data. Therefore, the higher learning institutions expected to conduct awareness campaigns among staff and students to any activity that could make the institution liable to offences under the Personal Data Protection Act 2010 such as screenshots of online classes, facial features of students, exposure of identity student number and other personal information (Omoola, 2020). Besides, appointment of a data protection officer and setting up of internal reporting procedures through an ombudsman in the university is needed (Omoola, 2020). This is supported by Chong (2020) stating that recruitment of digital forensics has to be increased to support tertiary education institutions.

The estimated number of youth unemployment is still high and has become the largest contribution to the unemployment issue in Malaysia (Nadarajah, 2020). This unemployment problem is due to the inability to compete with each other, skills mismatches, lack of job opportunities, lack of experience, job choices, limited soft skills, competing foreign workers and immigrants and the poor attitude of local workers (Abd Samad et al., 2019; Manshor et al., 2020). Government must take drastic steps to secure the youths with jobs soon after completing their studies such as giving the priority for youths to fill jobs compared to foreign workers. Another way is to strengthen the education-employment relationship as the main step in strengthening TVET (Özer, 2020). The government should primarily focus on strengthening the collaboration with the public and private sector under the Vocational Education Transformation Plan (Ministry of Education Malaysia, 2013). This is supported by COL (2020) stating that the government should build partnerships between educational organizations, industry and community groups for better understanding skill demands to transit learners into employment and self-employment.

The current crisis has pointed to a new opportunity for the TVET system and its learner, which can link education and business to support product and service design in some fields such as producing protective equipment and other supplies that can be used in health facilities. In Indonesia, efforts have been made especially training for medical equipment technicians, other health care workers as well as garment factory workers and call centre workers (The World Bank, 2020).

\subsection{TVET Institutions}

The TVET institutions are responsible for the engagement of students with e-learning by ensuring that Internet facilities are available for students. This facility needs to be emphasized as Internet networks (LAN, WAN or Internet) one of the important networks to convey content, information and to interact with it (Hassan et al., 2020). To overcome the Internet connection problem among instructors and students, the management of TVET institutions needs to enhance 
the exciting infrastructure of the hostel and college. This will increase the effectiveness of using e-learning among students and prevent students from dropping out. Besides, the TVET institutions could come up with new opportunities by developing digital infrastructure to expand and update technological infrastructure for digital pedagogy, investing in learning science and training of staff (The World Bank, 2020).

Furthermore, TVET institutions can provide free learning platforms or the quality web-based tools to reduce disruption online learning. The European Commission had asked European national public authorities to share the existing materials freely considering the difficulty to find materials online for TVET (Majumdar \& Araiztegui, 2020). The TVET institutions are suggested to set up their own e-campus as a platform to host and run e-learning courses or training to both students and instructors. This e-campus is operated by an online LMS, which runs as an application for the administration, documentation, tracking, reporting and delivery of educational, training, learning and development programs. Technical support should combine with expert support so that educational technology in TVET programs can be used completely. Expertise can provide various programs such as ICT courses for instructors to boost up the skills in ICT and technology for online learning purposes (Amran \& Yahya, 2020).

The revisions of curriculum, pedagogy, learning materials and assessments for TVET institutions should be conducted and paralleled with e-learning demand. TVET institutions should be ready to prepare detailed and well-structured lesson plans before furnishing their LMS with the appropriate content to stimulate learning among students. According to Krishnan (2020), TVET institutions can work well for online learning by applying the modules comprising 30 percent theory and 70 percent practical components. Besides, e-learning allows skills training institutes and providers to adapt to the assessment of students by external examiners. Therefore, the providers need to discuss the procedures of examination and accreditation that adapt to the new normal situation without hurting protocols and systems (Majumdar \& Araiztegui, 2020).

TVET institutions should consider blended learning, which makes it more flexible for instructors and students to carry out the learning process whenever they can access the Internet. In this current study, the providers must determine the instructional strategies for online learning including technology capacity such as TV learning, online applications and radio or offline materials such as modules, textbooks and printed materials to enhance the rate of success of online learning among learners (Rasmidatila et al., 2020). Besides that, TVET institutions can offer short courses, up-skilled courses or workforce training using MOOC or other similar platforms to enhance workers knowledge and skills in empowering TVET (Salleh \& Sulaiman, 2020).

Moreover, the academic supervision is responsible for improving the learning process. The academic supervision can improve the learning process through monitoring and controlling the teachers' teaching activities, help teachers to overcome their difficulties in using technology and planning and developing the 
program for teachers in handling online class and tasks so that the teachers' performance can be improved in online learning (Istiningsih et al., 2020). Baber (2020) also found that the providers' knowledge and support during online learning influenced the students and instructors' satisfaction and improved online learning quality.

Appointment basis should be allowed for students to meet with their lecturers which can be conducted in an open area where physical distancing is maintained. This would truly help students who have a hard time adapting to online teaching. Disadvantaged students should be given the option to apply for assistance such as facilities use permission from the institutions. The institutions can issue special passes for these students and stipulate that they can only be on campus for a specific period per day. Such arrangements will not only help in crowd control but also ensure that the less-privileged students will not fall behind. At the college or university level, instructors will need additional training in the use of online teaching tools and recording tools. Above all, universities and colleges will have to allocate additional funding to subsidize less-privileged students (Chong, 2020).

In order to reduce unemployment of TVET graduates, TVET institutions should be actively engaged with health facilities and services such as production of protective equipment, sanitizers and masks. Besides, they can be the volunteers in vaccination centres as most medical workers focus on patients. In some areas, they can link with repair and maintenance for health facilities needed to support in designing of product and service, development and distribution (Majumdar, 2021). From this opportunity, TVET institutions can be an important partner and build a bridge between education and business while enhancing students' knowledge, competencies and skills for future work and employment demand. Final-year students also can do a practical or internship in the health and safety areas (Majumdar, 2021).

\subsection{Instructor}

The collaboration among instructors to create an electronic platform is encouraged as some of TVET instructors have qualification in ICT. The use of LMS Moodle and MOOCs as a platform for online learning enables students to access educational content at any time and will reduce institutional barriers (Mohan et al., 2020; Min \& Nasir, 2020). The teaching materials in the electronic format such as electronic textbooks, study guides, tests and many more can be uploaded and downloaded by the students and teachers easily. According to Almazova et al. (2020) studies, Peter the Great St. Petersburg Polytechnic University organized educational activities in an electronic format for students online such as electronic information and educational resources, and telecommunication resources. From the cooperation with outside organizations, the collaborative teaching and learning can be implemented smoothly during the pandemic.

Although current T\&L are dependent through online, instructors are needed 
to be creative in pedagogy. According to Yusoff et al. (2017), gamification MOOC can enhance an interactive, interesting and creative learning for students. In other words, an experiment or lesson could be integrated with games to develop students' cognitive skills in specific concepts. Besides, Katam and Otieno (2021) stated that there are many online learning tools that can be used to provide learning materials such as MOOCs, television, webinars for discussion and master classes. Microsoft Teams, Zoom, Google Meet and other platforms also can be used for the interaction between the instructors and students through the automatic creation of webinar rooms.

The development of interactive T\&L such as gamification through quizzes, social and collaborative learning also can be created by the instructors to attract the interest of study among students (Talib et al., 2017). This technique allows students to share and expand their knowledge in an open forum effectively especially in education (Bączek et al., 2020). Problem-Based Learning (PBL) can be implemented with online discussion to enhance collaborative group work. Okolie et al. (2020) stated that integration of PBL in TVET education promotes active learning of students and stimulates them to question and deep learning at their own pace. Due to the pandemic, instructors can develop a problem statement in certain topics in LMS so that students can share their knowledge and solution with classmates. From that discussion, students can link what they have learned with the previous problem and instructors also can identify the cognitive development of the topics (Khalid \& Quick, 2016).

In order to make the T\&L process become more interactive, playful and experimental, instructors are encouraged to use web-based laboratories in teaching. According to Polat and Ekren (2020), students can gain access to computer-simulated processes through virtual labs while remote labs provide the ability for students to work with actual data rather than simulated ones. The use of web-based laboratories in TVET enables them to develop and prepare students in advance of practical training tasks in the lab. The study of Polat and Ekren (2020) stated that the web-based lighting laboratory infrastructure which allowed students practising the application through online real-time equipment increased the theoretical knowledge of doing remote experiments. Rahman et al. (2020) also reported that TVET education is based on performance-based learning and emphasized the practical skills. In order to enhance understanding of theoretical concepts, practical learning is important as a lecture support in concepts.

In Indonesia, Virtual Cloud Automotive Laboratory was designed to enable industries to share competency and occupational materials in light vehicle or automotive engines that can be accessed by students and lecturers (Dede et al., 2020). The Virtual Patients (VPs) model is a Web-based Simulation which was developed and used in Romania specifically for medical courses, therapeutic diagnosis and planning (Katam \& Otieno, 2021). Students will work as if the cases are real and useful for TVET students practice as a practical online. 
ICT integration in TVET curriculum facilitates instructors' teaching development as they implement new flexible learning methods, which enhance students' skills and lifelong learning (Ghavifekr \& Yulin, 2021). It's also supported that increasing the use of ICT directly proportional to economic development and education as most of the industries demand ICT skill from employees. Hence, ICT implementation in TVET education acts as an alternative face-to-face pedagogy and can be used widely in future parallel with face-to-face classroom as a supportive extension to students (Pangeni \& Karki, 2021).

Beside the use of electronic platforms, instructors also need to consider the ability of students to have internet access and digital tools as well. The World Bank (2020) stated that Direct-To-Home TV channels, mobile phones and interactive voice response (IVR) are widely used in India for their students' online TVET learning. This is due to low-economic students that cannot afford hightechnology digital tools. These alternative methods are low-technology training solutions and easy to use for instructors and students. Meanwhile, the study of Rusli et al. (2019) on the uses of Mobile Arc Welding Learning (MAWL) App for student in learning arc welding declared the application is easy to use, has an engagement with the subject, the students are able to learn the subjects virtually, and gives the motivation, usefulness and satisfaction to the students during virtual learning as the application provides additional information in electronic formats such as text, images, videos and 3D models. This proves that using mobile technology along with augmented reality has a wide potential in theoretical and practical works for TVET students. Shahrin et al. (2021) also supported the use of virtual simulators helping in minimizing the negative effects of the crisis and keeping the momentum in learning for TVET students.

In order to raise the enrolment of students in TVET education, the instructors should increase their quality of teaching through training and attachment schemes with the industry (Aziz et al., 2020). Yusof et al. (2020) also supported in their study that the instructors who teach in technology subjects need to have knowledge and information in industry so that they are always up-to-date in industry demand. The exposure with industry demand can decrease the competency gap possessed by the instructors (Kamaruddin \& Ibrahim, 2010).

\subsection{Parents}

Parents are playing an important role in the academic achievement of their children. In fact, parents are the closest people to their children and in this sense, children's education depends on the parents. According to Listyaningrum et al. (2020), involvement of parents is needed in assisting children from an early age by providing a conducive environment at home, learning experiences and support and showing a good attitude towards their children. Rahman et al. (2021) supported that the more parents spend more than two hours per day in children's education, the more the children achieve high academic performance at school.

Agreeing to Đurišić and Bunijevac (2017), involvement of parents as an educator 
for the children can improve academic performance of students in school. In their studies, there are five themes discussed including parenting knowledge, parenting skills in guiding children, social support, motivation and self-management of parents and parents' self-esteem. Based on the result, most of the parents chose to agree with the essential parenting knowledge to enhance the development of their children's cognitive development, learning and self-efficacy. Besides, parents need social support for children protection, quality of care and children's flexibility, the needs of motivation and self-management among parents to support children's education at home and self-esteem is essential for parents in mentoring children during learning from home are required to educate and monitor of children's education in informal learning at home (Listyaningrum et al., 2020).

\section{Conclusion}

Based on the discussion of this review paper, TVET education showed that all parties such as instructors, students and TVET institutions are facing the challenges and impact from transition of conventional teaching and learning to online learning. From an overview, TVET institutes, instructors and students are not fully ready to migrate into online learning, as the TVET programs require practical skills and work-based learning rather than theoretical teaching. Through learning from home, some practical exercises, which require a certain use of requirements or materials are not usually found at the home and give a negative impact on the attitude and motivation of students in learning. Due to the pandemic, some instructors have insufficient skills in e-learning usage and adaptation in pedagogies, strategies and methods, classroom management and assessment, and integrating ICTs in teaching and learning. From students' view, they have problems in necessary skills for remote training, poor internet connectivity, usability of learning plat-forms and need more time for videos and online learning preparation. As a result, training in basic skills for e-learning for instructors and students are essential for familiarization with e-learning facilities utilization skills. To overcome these challenges, the provider and policy maker, instructors, TVET institutions, and parents play an important role to improve the effectiveness of online learning. The provider and policy maker should take initiative by providing instruments and Internet packages needed for students, the instructors should provide free learning platforms or the quality web-based tools for easily used by students while parents need to assist their children's education to enhance their academic achievement and encouragement in study. Without the collaborations, the solutions cannot be achieved for TVET students and instructors in new norm learning.

\section{Acknowledgements}

The authors would like to thank Ts. Dr. M. Khalid M. Nasir for his contribution and Faculty of Education, The Universiti Kebangsaan Malaysia (UKM) for sup- 
porting this review paper.

\section{Conflicts of Interest}

The authors declare no conflicts of interest regarding the publication of this paper.

\section{References}

Abd Samad, N., Ghazalan, M. S., Wan Ahmad, W. M. R., Ismail, A., Harun, H., Ismail, M. E., Amiruddin, M. H., \& Razali, N. (2019). Level of Readiness to Become Entrepreneurs among Lifelong Learning Programmes Participants in Malaysian Community Colleges. Journal of Technical Education and Training, 11, 143-150.

Ahmad, N. A., Elias, N. F., \& Sahari@Ashaari, N. (2019). The Importance of the Psychomotor Factors for Effective Learning Management System Use in TVET. International Visual Informatics Conference, Bangi, 19-21 November 2019, 620-627. https://doi.org/10.1007/978-3-030-34032-2_55

Almazova, N, Krylova, E., Rubtsova, A., \& Odinokaya, M. (2020). Challenges and Opportunities for Russian Higher Education Amid Covid-19: Teachers' Perspective. Education Sciences, 10, 368-379. https://doi.org/10.3390/educsci10120368

Amran, M., \& Yahya, M. Z. (2020). Faktor Dan Persepsi Yang Mempengaruhi Penggunaan Teknologi dalam pendidikan di kalangan pensyarah kolej komuniti. International Journal of Technology Management and Information System, 2, 72-80.

Arshad, M., Tahir, A., Khan, M. M., \& Basit, A. (2018). Impact of Career Counseling \& Vocational Guidance on Employment in TVET Sector. International Journal of Human Resource Studies, 8, 274-289. https://doi.org/10.5296/ijhrs.v8i1.12554

Ating, R. (2020, June 30). Challenges to Learning and Teaching in Malaysia in the Time of COVID-19. Strengthening Human Rights and Peace Research and Education in ASEAN.

https://shapesea.com/op-ed/covid-19/challenges-to-learning-and-teaching-in-malaysia -in-the-time-of-covid-19/

Aziz, S. N. A., Zulkifli, A., Mat Nashir, I., \& Karim, N. A. A. (2020). Pull and Push Factors of Stu-dents' Enrolment in the TVET Programme at Community Colleges in Malaysia. Journal of Technical Education and Training, 12, 68-75.

Baber, H. (2020). Determinants of Students' Perceived Learning Outcome and Satisfaction in Online Learning during the Pandemic of COVID19. Journal of Education and e-Learning Research, 7, 285-292. https://doi.org/10.20448/journal.509.2020.73.285.292

Bączek, M., Zagańczyk-Bączek, M., Szpringer, M., Jaroszyński, A., \& Wożakowska-Kapłon, B. (2020). Students' Perception of Online Learning during the COVID-19 Pandemic: A Survey Study of Polish Medical Students. Medicine, 100, e24821.

https://journals.lww.com/md-journal/Fulltext/2021/02190/Students_perception_of_o nline_learning_during_the.87.aspx

Bakri, A., \& Zakaria, I. H. (2018). Uplifting the Function of Maintenance Management towards Sustainable Performance of Laboratory and Workshop in TVET Institutions. The Journal of Social Sciences Research, No. 6, 153-160. https://doi.org/10.32861/jssr.spi6.153.160

Chong, P. Y. (2020, May 8). COVID-19: Impact on the Tertiary Education Sector in Malaysia. Penang Institute.

https://penanginstitute.org/publications/covid-19-crisis-assessments/covid-19-impacton-the-tertiary-education-sector-in-malaysia/ 
Commonwealth of Learning (COL) (2020). Strategies for Blended TVET in Response to COVID-19.

http://oasis.col.org/bitstream/handle/11599/3624/2020_COLStrategies_for_blended_T VET_COVID19.pdf?sequence $=1$ \&isAllowed $=$

Dede, Abdullah, A. G., Mulyanti, B., Rohendi, D., \& Sulaeman (2020). TVET Learning Innovation on Automotive Virtual Laboratory Based on Cloud Openstack. Journal of Technical Education and Training, 12, 51-60.

Dumbiri, D. N., \& Nwadiani, C. O. (2020). Challenges Facing Application of E-Learning Facilities in Vocational and Technical Education Program in South Nigeria Universities. Asian Journal of Vocational Education and Humanities, 1, 1-13.

Đurišić, M., \& Bunijevac, M. (2017). Parental Involvement as an Important Factor for Successful Education. Center for Educational Policy Studies Journal, 7, 137-153.

Dyrin, S., Kornilova, I., Sabirov, I., Asratyan, N., Vazieva, A., \& Gayfutdinova, T. (2021). Life Plans of Graduates of Technical and Vocational Education Institution. SHS Web of Conferences, 97, Article ID: 01046.

Ghavifekr, S., \& Yulin, S. (2021). Role of ICT in TVET Education: Teaching \& Learning Amid COVID-19 Pandemic. International Journal of Advanced Research in Education and Society, 3, 119-131.

Hanapi, Z., Safarin, M., \& Che, R. (2015). Unemployment Problem among Graduates of Technical Field: Competencies of the Graduates and Quality of the Education. Sains Humanika, 2, 53-57. https://doi.org/10.11113/sh.v2n2.414 https://sainshumanika.utm.my/index.php/sainshumanika/article/view/414

Hasin, I., \& Nasir, M. K. M. N. (2021). The Effectiveness of the Use of Information and Communication Technology (ICT) in Rural Secondary Schools in Malaysia. Journal of Education and E-Learning Research, 8, 59-64. https://doi.org/10.20448/journal.509.2021.81.59.64

Hassan, W. A. S. W., Ariffin, A., Ahmad, F., Sharberi, S. N. M, Nor Azizi, M. L., \& Zulkiflee, S. N. (2020). COVID-19 Pandemic: Langkawi Vocational College Student Challenge in Using Google Classroom for Teaching and Learning (T \& L). International Journal of Advanced Trends in Computer Science and Engineering, 9, 3299-3305. https://doi.org/10.30534/ijatcse/2020/127932020

Hayashi, R., Jayasundara, H. D. S. A., Garcia, M., Balasuriya, A., \& Hirokawa, T. (2021). COVID-19 Impact on Technical and Vocational Education and Training in Sri Lanka. ADB Briefs, 168, 1-8. https://doi.org/10.22617/BRF210081-2

Hoftijzer, M., Levin, V., Santos, I., \& Weber, M. (2020, May 4). TVET in the Times of COVID-19: Challenges and Opportunities.

https://blogs.worldbank.org/education/tvet-technical-and-vocational-education-and-tr aining-times-covid-19-challenges-and

Hong, C. M., Ch'ng, C. K., \& Roslan, T. R. N. (2021). Students' Tendencies in Choosing Technical and Vocational Education and Training (TVET): Analysis of the Influential Factors Using Analytic Hierarchy Process. Turkish Journal of Computer and Mathematics Education, 12, 2608-2615. https://doi.org/10.17762/turcomat.v12i3.1262

International Labour Organization (ILO) (2020). ILO-UNESCO-WBG Joint Survey on Technical and Vocational Education and Training (TVET) and Skills Development during the time of COVID-19. International Labour Organization.

https://www.ilo.org/wcmsp5/groups/public/---ed_emp/---emp_ent/documents/generic document/wcms_742817.pdf

Ismail, A., \& Abiddin, N. Z. (2014). Issues and Challenges of Technical and Vocational Education and Training in Malaysia towards Human Capital Development. Mid- 
dle-East Journal of Scientific Research, 19, 7-11.

Ismail, K., Mohd Nopiah, Z., \& Mohd Sattar, R. (2018). Challenges Faced by Vocational Teachers in Public Skills Training Institutions: A Reality in Malaysia. Journal of Technical Education and-Training (JTET), 10, 13-27. https://doi.org/10.30880/jtet.2018.10.02.002

Istiningsih, E., Sutyano, \& Widodo (2020). Academic Supervision to Improve Teachers' Readiness in Utilizing Information and Communication Technology in Vocational High Schools. Universal Journal of Educational Research, 8, 4365-4373.

https://www.hrpub.org/download/20200930/UJER2-19515992.pdf https://doi.org/10.13189/ujer.2020.081002

Jalli, N. (2020, April 7). Commentary: E-Learning Sees No Smooth Sailing in Malaysia and Indonesia. Channel New Sasia.

https://www.channelnewsasia.com/news/commentary/coronavirus-covid-19-malaysiai ndonesia-school-e-learning-online-12616944

Kamaruddin, W. N. W., \& Ibrahim, M. S. (2010). Lecturer Efficacy, Professional and General Competencies of Malaysian Polytechnic Technical Lecturers. RCEE \& RHEd2010, Kuching, 7-9 June 2010, 1-8.

http://tree.utm.my/wp-content/uploads/2013/03/Lecturer-Efficacy-Professional-and-G eneral-Competencies-of-Malaysian-polytechnic-technical-lecturers.pdf

Katam, E., \& Otieno, D. (2021). A Review of Technical and Vocational Education and Training Institutions' Online Learning as a Response to Corona-Virus Disease 2019 in Kenya. The Kenya Journal of Technical and Vocational Education and Training, 4, 96-105.

https://ziziafrique.org/wp-content/uploads/2019/05/TVETA-Journal-for-web.pdf\#page $=105$

Khalid, N. M., \& Quick, D. (2016). Teaching Presence Influencing Online Students' Course Satisfaction at an Institution of Higher Education. International Education Studies, 9, 62-70. https://doi.org/10.5539/ies.v9n3p62

Krishnan, D. B. (2020, November 8). TVET Plan a Success. New Straits Times. https://www.nst.com.my/news/nation/2020/11/639271/tvet-plan-success

Lie, A., Tamah, S. M., Gozali, I., Triwidayati, K. R., Utami, T. S. D., \& Jemadi, F. (2020). Secondary School Language Teachers' Online Learning Engagement during the COVID-19 Pandemic in Indonesia. Journal of Information Technology Education: Research, 19, 803-832. https://doi.org/10.28945/4626

https://www.informingscience.org/Publications/4626?Source=\%2FJournals\%2FJITERe search\%2FArticles\%3FVolume $\% 3 \mathrm{D} 0-0$

Listyaningrum, R., A., Widyaswari, M., Sari, N., N., \& Yuniar, D., P. (2020). Analysis of the Needs of Parents in Mentoring Early Childhood during Learning from Home. Proceedings of the 2nd International Conference on Early Childhood and Primary Childhood Education (ECPE), 3 October 2020, 223-229.

https://doi.org/10.2991/assehr.k.201112.039

Mahuyu, J., \& Makochekanwa, A. (2020). Perspectives of Parents towards Technical and Voca-tional Education and Training (TVET) in Zimbabwe. Advances in Politics and Economic, 3, 1-7. https://doi.org/10.22158/ape.v3n4p1 https://pdfs.semanticscholar.org/be81/0504cb93d3455acb67dd46acb179d638ec05.pdf

Majumdar, S. (2021). TVET in the Time of COVID-19 and After. AfriTVET, 6, 1-13. http://afritvet.org/Articles/TVET\%20in\%20the\%20Time\%20of\%20Covid-19\%20and\%2 0after.pdf

Majumdar, S., \& Araiztegui, I. (2020). Technical Vocational Education \& Train- 
ing-Reflections on the Issues Facing TVET and Its Potential in the Time of COVID-19 (pp. 9-22). Colombo Plan Staff College (CPSC).

https://pub.cpsctech.org/steps04/

Manshor, Z., Abdullah, S., \& Takiyudin, M. A. (2020). Social Entrepreneurship and TVET: Tracking Youth Unemployment. International Journal of Academic Research in Business and Social Sciences, 10, 1408-1413.

https://hrmars.com/papers/detail/IJARBSS/8364

https://doi.org/10.6007/IJARBSS/v10-i11/8364

Menon, S. (2020, May 3). Skills Training Goes Online. The Star. https://www.thestar.com.my/news/education/2020/05/03/skills-training-goes-online

Min, H., \& Nasir, M. K. M. (2020). Self-Regulated Learning in a Massive Open Online Course: A Review of Literature. European Journal of Interactive Multimedia and Education, 1, e02007. https://doi.org/10.30935/ejimed/8403

Ministry of Education Malaysia (2013). Malaysia Education Blueprint 2013-2025. Ministry of Education Malaysia.

Mohan, M. M., Upadhyaya, P., \& Pillai, K. R. (2020). Intention and Barriers to Use MOOCs: An Investigation among the Post Graduate Students in India. Education and Information Technologies, 25, 5017-5031. https://doi.org/10.1007/s10639-020-10215-2 https://www.researchgate.net/publication/341421965_Intention_and_barriers_to_use_ MOOCs_An_investigation_among_the_post_graduate_students_in_India

Moodie, G. (2002). Identifying Vocational Education and Training. Journal of Vocational Education and Training, 54, 249-266. https://doi.org/10.1080/13636820200200197

Munyi, F. W., Okinda, R., \& Wambua, F. (2021). E-Learning Adoption Model in TVET Institutions in Kenya during and Post COVID-19. International Journal of Applied Computer Science, 6, 1-10.

https://www.academicinsights.org/index.php/IJACS/article/view/55

Nadarajah, D. (2020, November 13). We Should Nurture a Culture That Values Vocational Education. New Straits Times.

https://www.nst.com.my/opinion/columnists/2020/11/640654/we-should-nurture-cult ure-values-vocational-education

Nasir, M. K. M. (2020). The Influence of Social Presence on Students' Satisfaction toward Online Course. Open Praxis, 12, 485-493. https://doi.org/10.5944/openpraxis.12.4.1141

Nasir, M. K. N., Mansor, A. Z., \& Rahman, M. J. A. (2018). Measuring Malaysian Online University Student Social Presence in Online Course Offered. Journal of Advanced Research in Dynamical and Control Systems, 10, 1442-1446.

Nasir, M., Alvi, A. S., \& Tarar, M. G. (2021). Role of Technical Education and Vocational Training in Promoting Youth Employment: A Case study of TVET Institutes in District Gujranwala. Pakistan Social Sciences Review, 5, 402-413.

http://doi.org/10.35484/pssr.2021(5-I)31

https://pssr.org.pk/issues/v5/1/role-of-technical-education-and-vocational-training-inpromot-

ing-youth-employment-a-case-study-of-tevt-institutes-in-district-gujranwala.pdf

Nassr, R. M., Aborujilah, A., Aldossary, D. A., \& Aldossary, A. A. A. (2020). Understanding Education Difficulty during COVID-19 Lockdown: Report on Malaysian University Students' Experience. IEEE Access, 8, 186939-186950.

https://doi.org/10.1109/ACCESS.2020.3029967

Ngampornchai, A., \& Adam, J. (2016). Students' Acceptance and Readiness for E-Learning in Northeastern Thailand. International Journal of Educational Technology in Higher Education, 13, Article No. 34. https://doi.org/10.1186/s41239-016-0034-x 
Okolie, U. C., Elom, E. N., Igwe, P. A., Binuomote, M. O., Nwajiuba, C. A., \& Igu, N. C. N. (2020). Improving Graduate Outcomes: Implementation of Problem-Based Learning in TVET Systems of Nigerian Higher Education. Higher Education, Skills and Work-Based Learning, 11, 92-110. https://sci-hub.se/10.1108/HESWBL-12-2018-0140 https://doi.org/10.1108/HESWBL-12-2018-0140

Omar, M. K., Ismail, N., Rauf, M. A., \& Puad, M. H. M. (2020). Factors on Deciding TVET for First Choice Educational Journey among Pre-Secondary School Student. European Journal of Molecular \& Clinical Medicine, 7, 609-622.

Omoola, S. (2020, July 23). A Wake-Up Call for Data Protection. TheStar. https://www.thestar.com.my/opinion/letters/2020/07/23/a-wake-up-call-for-data-prote ction

Özer, M. (2020). Vocational Education and Training as "A Friend in Need" during Corona Virus Pandemic in Turkey. Bartın University Journal of Faculty of Education, 9, 1-7.

Pangeni, S. K., \& Karki, G. (2021). E-Learning Initiatives at CTEVT: An Attempt at Innovation and Paradigm Shift in TVET Pedagogy. Journal of Technical and Vocational Education and Training, 1, 134-147.

Polat, Z., \& Ekren, N. (2020). Remote Laboratory Trends for Distance Vocational Education and Training (D-VET): A Real-Time Lighting Application. The International Journal of Electrical Engineering \& Education, 1, 1-16. https://doi.org/10.1177\%2F0020720920926679

Rahman, A. A., Hanafi, N. M., Yusof, Y., Mukhtar, M. I., Awang, H., \& Yusof, A. M. (2020). The Effect of Rubric on Rater's Severity and Bias in TVET Laboratory Practice Assessment: Analysis using Many-Facet Rasch Measurement. Journal of Technical Education and Training, 12, 57-67.

Rahman, M. M., Rashid, M., \& Khan, M. S. (2021). Parents' Involvement in Children's Education: A Study on Kachua Upazila of Bagerhat, Bangladesh. Journal of Media and Communication Studies, 1, 86-101.

Rasmidatila, Aliyyah, R. R., Rachmadtullah, R., Samsudin, A., Syaodih, E., Nurtanto, M., \& Tam-Bunan, A. R. S. (2020). The Perceptions of Primary School Teachers of Online Learning during the COVID-19 Pandemic Period: A Case Study in Indonesia. Journal of Ethnic and Cultural Studies, 7, 90-109. https://doi.org/10.29333/ejecs/388

Rusli, F. N., Zulkifli, A. N., Saad, M. N., \& Yussop, Y. M. (2019). A Study of Students' Motivation in Using the Mobile Arc Welding Learning App. International Journal of Interactive Mobile Technologies, 13, 89-105. https://doi.org/10.3991/ijim.v13i10.11305

Salleh, K. M., \& Sulaiman, N. L. (2020). Reforming Technical and Vocational Education and Training (TVET) on Workplace Learning and Skills Development. International Journal of Recent Technology and Engineering (IJRTE), 8, 2964-2967. https://doi.org/10.35940/ijrte.E6553.018520

Sauffie, N. F. M. (2015). Technical and Vocational Education Transformation in Malaysia: Shaping the Future Leaders. Journal of Education and Practice, 6, 85-89.

Shahrin, S., Rosli, A., Hadi, M. H. J. A., \& Awang, H. (2021). A Theoretical framework of Secure Environment of Virtual Reality Application in Tertiary TVET Education using Blockchain Technology. Journal of Contemporary Social Sciences Studies, 1, 39-46.

Sitepu, E. S., Nursiah, \& Azhar, A. (2020). The Role of Intellectual, Emotional and Spiritual Intelligence towards Entrepreneurial Intention among TVET Students Indonesia and Malaysia. International Journal of Technical Vocational and Engineering Technology, 2, 117-123.

Sufian, S. A., Nordin, N. A., Tauji, S. S. N., \& Nasir, M. K. M. (2020). The Impact of Co- 
vid-19 on the Malaysian Education System. International Journal of Academic Research in Progressive Education \& Development, 9, 764-774.

https://doi.org/10.6007/IJARPED/v9-i2/7659

Tadele, G., \& Terefe, E. (2018). Influence of Career Self-Efficacy Beliefs on Career Exploration Behaviours among TVET College Students in Wollega Zones Town. Science, Technology and Arts Research Journal, 5, 108-114. https://doi.org/10.4314/star.v5i1.17

Talib, N., Yassin, S. F. M., \& Nasir, M. K. M. (2017). Teaching and Learning Computer Programming Using Gamification and Observation through Action Research. International Journal of Academic Research in Progressive Education and Development 2017, 6, 1-11. https://doi.org/10.6007/IJARPED/v6-i3/3045

Thangaiah, E. A., Jenal, R., \& Yahaya, J. (2020). Penerokaan Penggunaan E-Pembelajaran dalam Kalangan Pelajar dan Pengajar TVET-Satu Kajian Awal. Journal of Southeast Asia Social Science \& Humanities (Akademika), 3, 5-18.

The World Bank (2020). East Asia and Pacific: Tertiary Education. COVID-19 Coronavirus Response. World Bank.

http://documents1.worldbank.org/curated/en/506241590701178057/COVID-19-Impac t-on-Tertiary-Education-in-East-Asia-and-Pacific.pdf

UNESCO-UNEVOC International Centre (2020). Skills for a Resilient Youth: Virtual Conference Report.

http://oasis.col.org/bitstream/handle/11599/3648/2020_Neal_Virtual_Conference_Skill s_for_Resilient_Youth.pdf?sequence $=1$ \&isAllowed $=\mathrm{y}$

United Nations Educational, Scientific and Cultural Organization (UNESCO) (2020). Records of the 31st Session of the General Conference: Resolutions (p. 28). United Nations Educational, Scientific and Cultural Organization. https://unesdoc.unesco.org/ark:/48223/pf0000124687

Yasak, Z., \& Alias M. (2015). ICT Integrations in TVET: Is It up to Expectations? Procedia-Social and Behavioral Sciences, 204, 88-97. https://doi.org/10.1016/j.sbspro.2015.08.120

Yusof, M. H. M., Arsat, M., Amin, N. F., \& Latif, A. A. (2020). Issue and Challenge for Vocational Teaching Quality in the Vocational College Lecturers: A Systematic Review. Sains Humanika, 12, 9-13.

Yusoff, A. M., Salam, S., Mohamada, S. N. M., \& Daud, R. (2017). Gamification Element through Massive Open Online Courses in TVET: An Analysis Using Analytic Hierarchy Process. Advanced Science Letters, 23, 8713-8717. https://doi.org/10.1166/asl.2017.9956

Zulkifli, N., Hamzah, M., \& Bashah, N. (2020). Challenges to Teaching and Learning Using MOOC. Creative Education, 11, 197-205. https://doi.org/10.4236/ce.2020.113014 